Article

\title{
Digital Technologies at the Pre-University and University Levels
}

\author{
Francisca Angélica Monroy García ${ }^{1, *}$, Fátima Llamas-Salguero ${ }^{1}[$, \\ María Rosa Fernández-Sánchez ${ }^{1}$ (1) and José Luis Carrión del Campo ${ }^{2}$ \\ 1 Department of Educational Sciences, University of Extremadura, 06006 Badajoz, Spain; \\ fatimalls@unex.es (F.L.-S.); rofersan@unex.es (M.R.F.-S.) \\ 2 Freelance Psychologist, 30007 Murcia, Spain; joseluiscarrion@yahoo.es \\ * Correspondence: frmonroyg@unex.es; Tel.: +34-679-052-113
}

Received: 7 November 2020; Accepted: 9 December 2020; Published: 13 December 2020

check for updates

\begin{abstract}
The education sector is undergoing significant challenges in the process of transforming learning models in order to face the new requirements of our hyper-connected society. Teaching students how to adequately interact as active and committed citizens in our knowmadic global society is the most challenging task facing educators nowadays. Moreover, the university must consider a student's knowledge of digital technologies to be able to design new educational models that respond to their current needs. The aim of our research is to assess that knowledge and the use of digital technologies among college students and the relationship this has with their prior academic experience. Data collection included a validated ad-hoc questionnaire divided into 16 categories applied to 757 students of both sexes between 20 and 57 years of age. The results show that, irrespective of gender and age, those students who have used Information and Communication Technologies (ICT) in their secondary education have a better knowledge of how to use them to their advantage throughout their university learning process. In conclusion, students need to undergo a training in digital skills before entering university, so as to equip them with a higher level of digital competence.
\end{abstract}

Keywords: ICT; competence; secondary education; university; learning strategies; educational innovation

\section{Introduction}

In today's society, hyperconnectivity is experienced by some people on a daily basis [1] and is seen as the third driving force in human development due to its mediating role in the mutual relations between humans and technology [2] Psychosocial patterns constantly change [3] allowing people and communities to use their oral and visual culture in producing new practices. Today's environment is increasingly creative and innovative: new patterns of reading and writing are emerging in which there are new multiliteracy processes and connected televisions [4-6]. This is a context which invites us to be a part of the consumerist army and the cultural output [7].

We in the education sector must tackle the challenges which arise from this reality and above all must analyse the ability to generate processes, projects, and action plans to train everyone so that they can fully participate as citizens in the current society [7]. The creation of suitable working conditions in educational institutions is essential to develop education projects capable of combining learning experiences and multi-contextual type skills [8,9] in non-formal, flexible, and self-managed education environments $[10,11]$ where the learning process is constantly changing. This results in a requirement for new skills and competences in a new citizenry who can thus respond to the demands posed by the twenty-first century. At the same time, a series of new tendencies is emerging in our knowmadic society [12] such as: the use of informal and flexible learning methods related to continuing education which change what and how we learn; the role of ICT and new literacy studies; and the development 
of skills in critical thinking to assist learning experiences in contexts which are multiple and changing by means of experimentation, observation, and peer exchange.

\section{Digital Technologies and Their Impact on Pre E Post-University Levels}

The term "competence" has gained ground in recent years and nowadays is a concept widely used by educators: any development project or education cycle is based upon the competences that individuals need to acquire. One key competence at all stages of education is that of digital competence [13], widely used in political rhetoric and documents around the world. Nevertheless, there is no comprehensive definition of digital competence due to its multidisciplinary use, diverse epistemological origin, and its relation with similar terms caused by some conceptual approaches to the definition by multiple studies [14-19]. It is clear, though, that the concept is acquiring a pedagogical perspective [20] which requires an array of skills, abilities and attitudes approached from different areas of knowledge [21]. In Europe, the education systems are reformulating the university curriculum, not only in terms of contents but also approach, to strengthen students' digital competence [22]. Thus, the education system is experiencing a paradigmatic shift which is giving rise to new learning environments which foster new educational projects led by digital technologies. These projects awaken the interest and commitment of young people and produce new ways of cooperation within these new information environments. As a result, learning processes different to the traditional school system are being created through the informal creation of interest groups [23] learning communities [24], affinity spaces [25], and social networks [26].

Meanwhile, the increasing digitalization of our societies requires countries to develop strategies that enable them to satisfy the demand for a high-quality digital education [22]. Thus, the importance of technological innovation, and its relevance in the context of education, is nowadays unquestioned. In the last few years, digital technologies have become incorporated at all levels of education and changes in the profiles of teacher and student have become evident [27,28]. However, research reveals that the use of digital technologies in the classroom has not had the expected results as concerns an improvement in the teaching-learning process [29-33]. Nevertheless, these technologies afford the opportunity to establish effective creative learning environments in the teaching-learning processes, leading to important changes in the roles of both students and teachers [34], the facilitating of individualized learning, and improvements in students' motivation.

Studies on digital technologies among students in compulsory education deal with the self-perception of the students as regards their own digital competences [35,36]. These studies confirm that students perceive themselves as having a greater competence in instrumental skills and a lesser competence in such things as their critical, ethical, and reflexive analysis of the use of information and communication technologies [35].

As studies show, there is no such thing as a homogeneous digital generation; there are different profiles depending on their access to technology; the exposure to them, and the use of technologies [37]. It should be emphasised that there is a different use of technologies among young people: they may use these technological skills to socialise but they are not able to transfer them to their own learning processes [38]. López-Meneses et al. [39], in their research on ICT and university students, found two profiles with regard to the use of technologies: those who mostly use them to socialise or play; and those who use them to search for information and to complete their academic papers. In addition, self-testing students' awareness and use of technologies when they enter university will ensure that the learning process at higher education levels is oriented to producing citizens who are digitally competent and who can participate in a digitalized society [40]. Recent studies confirm that a student's real digital competences and previous ICT experience are related to the degree of self-perception of their own competence [41].

A current study shows that a positive relation exists between the use of the internet to socialise and the self-perception of digital competence, with no significant differences between the sexes [42]. The perception of those students with a higher level of academic achievement in the university is that 
the ICT are a potential resource to aid their learning, as they facilitate academic tasks. According to a study by García-Valcárcel \& Tejedor [43], these are usually students who already have a certain command of ICT and who employ cognitive strategies for the processing of information. Nevertheless, other studies on first-year university students [44] identify only weak links between these learning techniques and ITC skills. This highlights the importance of the relationship between teaching and technology (the pedagogical use of technology) in students' education. In fact, various studies link the greater frequency in the use of an internet-connected computer with the development of technological and pedagogical abilities, finding a significant relationship between these variables [45-47].

Considering all these questions, we ask: do the experiences of using technology in secondary school have a bearing on the perception and use of technology among university students? And what differences exist between these prior studies and the knowledge of ICT that university students have? Does gender influence the knowledge and use of ICT in so far as the academic experience prior to university is concerned? In this work, we aim to advance on such studies, analysing the knowledge and use of digital technologies among university students and the relationship this has with the academic experience they had prior to university, taking account of the means of access to university and the variable of sex.

\section{Materials and Methods}

The description of the variables was addressed in accordance with their nature; the qualitative ones by means of frequency (f) and percentage (\%), and the quantitative ones, having first checked the supposition of normality using the Shapiro-Wilk's test (S-W), by means of the mean $[\mathrm{M}]$ or the median [Med], and the Standard Deviation [DT] or the interquartile range [IQR]. The detection of outliers was done using the graphic test Boxplot. The analysis of the relations between the variables was done based on the correlation tests of Pearson's $r$ for the normal variables and Spearman's rho for the non-normal ones. The comparisons of averages were conducted with reference to the Student's $t$-test $(t)$ in the parametric cases and with reference to the Mann-Whitney u-test $(U)$ for the non-parametric ones. The reliability check of the groups of items was calculated by means of the test of Cronbach's alpha $(\alpha C)$. A type I error of $5 \%$ was applied throughout (risk $\alpha=0.05$ ).

The principal aim of this investigation is to analyze the use of digital technologies and the awareness of the advantages that these technologies present in processes of university teaching-learning and with regards to the academic experience of students at levels prior to higher education. As such, the study is based on a quantitative perspective, observational, transverse in nature, in which the following hypotheses are used:

- Students who in secondary education use ICT tools and digital learning materials show a greater awareness of the advantages of using ICT in their learning process than the students who do not use this type of material

- Students who enter university by means of a vocational training course show a greater awareness of ICT than those students who enter through the university access exam or the entry exam for students above 25 years of age.

Questionnaires were distributed to students from various fields of study in the University of Extremadura (Spain).

\subsection{Procedure}

The data were compiled in a questionnaire completed by the students themselves, with questions in two blocks:

- Students' personal information and sociodemographic issues. Fundamentally, these will be independent variables.

- Data under study: knowledge, valuation, and use of ICT in their past and current academic studies. Basically, these will be dependent variable. 


\subsection{Sample}

A sample was taken from among students in their final academic years of various fields of study (Arts \& Humanities, Health Sciences, Social \& Legal Sciences, Science, Architecture and Engineering) in a manner that was intentionally non-probabilistic (involving students who happened to be present on the date of the questionnaire). The sample covered 757 students in the districts of Badajoz and Cáceres (Spain). Of these, 291 were males (38.4\%) and 466 were females $(61.1 \%)$, aged between 20 and 57 years $(\mathrm{Med}=21, \mathrm{IQR}=2)$. The variable "Age" is not normally distributed $(\mathrm{SW}=0.826, p<0.001$ ). In the sample, the presence of outliers was controlled: students younger than 20 years or older than 27 years of age were controlled. Hence, we counted only the replies of 714 students. Of this final sample, $95.5 \%$ held no other university degree, with most (92.8\%) having entered university through the university access exam, as shown in Table 1.

Table 1. Distribution of the sample by holding another university degree and by means of university access exam.

\begin{tabular}{ccc}
\hline VOE-G & Frequency & $\%$ \\
\hline Holding Other University Degree & \\
\hline No & 676 & 95.5 \\
Yes & 32 & 4.5 \\
Type of University Access & & \\
Vocational training course & 51 & 7.2 \\
University access exam or aged above 25 years & 662 & 92.8 \\
\hline
\end{tabular}

Source: Author's own compilation.

\subsection{Instruments}

The questionnaire on the level of ICT Competences of the students includes 174 Likert items (1-None, 2-Little, 3-Some, 4-A lot). The questionnaire is organized into 16 groups: (1) Training: 9 items concerning the level of knowledge in ICT acquired prior to university. (2) Knowledge and usage: 15 items concerning the knowledge and use of ICT by students in performing academic tasks. (3) Knowledge (communication): 11 items concerning the use of ICT as a means of communication between students and teachers. (4) Knowledge (information): 7 items concerning the use of virtual resources available in the University of Extremadura (UEx).

- Teaching methodology: 11 items concerning the use of ICT by teachers in the classroom.

- Advantages offered by ICT: 15 items concerning the value which ICT have for students.

- Knowledge and use of programs: $15+15$ items concerning students' knowledge and use of 15 programs.

- Knowledge and use of browsers: $9+9$ items concerning students' knowledge and use of 9 browsers.

- Knowledge and use of search engines: $11+11$ items concerning students' knowledge and use of 11 search engines.

- Knowledge and use of websites: $9+9$ items concerning students' knowledge and use of 9 websites.

- Knowledge and use of communication tools: $9+9$ items concerning students' knowledge and use of 9 tools.

The Cronbach's Alpha score is 0.9, thus conferring upon the questionnaire a high degree of reliability.

\subsection{General Variables Studied (VOE-G by Its Acronym in Spanish) [(VOE-G)]}

Five variables were selected from the whole set:

(1) Training in ICT.

(2) Advantages offered by ICT and others made up of a linear combination of variables. 
(3) General knowledge of ICT resources and tools (as $\Sigma$ of 5):

- Knowledge of IT programs

- Knowledge of web browsers

- Knowledge of web search engines

- Knowledge of the web, common usage

- Knowledge of ICT applications and tools.

(4) General use of ICT resources and tools, (as $\Sigma$ of como 5):

- Use of IT programs

- Use of web browsers

- Use of web search engines

- Use of webs, common usage

- Use of ICT applications and tools.

(5) Knowledge and general use of ICT resources and tools (as $\Sigma$ of 2):

- General knowledge of ICT resources and tools

- General use of ICT resources and tools.

All the variables demonstrated a reliability between "good" (Advantages offered by ICT, General knowledge of ICT resources and tools, Knowledge and general use of ICT resources and tools) and "questionable" (General use of ICT resources and tools), and were labelled Global Variables Studied [(VOE-G)] (Table 2).

Table 2. Descripción de las VOE-G.

\begin{tabular}{cccccc}
\hline VOE-G & Reliability & S-W & $p$ & Med & DE, IQR \\
Training in ICT & $0.714(2)$ & 0.99 & $<0.001$ & $21 \mathrm{a}$ & $5 \mathrm{c}$ \\
Advantages offered by ICT & $0.874(1)$ & 0.99 & $<0.001$ & $44 \mathrm{a}$ & $9 \mathrm{c}$ \\
General knowledge of ICT tools and resources & $0.811(1)$ & 0.99 & 0.006 & $98 \mathrm{a}$ & $26 \mathrm{c}$ \\
General use of ICT tools and resources & $0.689(3)$ & 0.99 & $<0.001$ & $93 \mathrm{a}$ & $22 \mathrm{c}$ \\
Knowledge and general use of ICT tools and resources & $0.867(1)$ & 1.00 & 0.056 & $190.34 \mathrm{~b}$ & $31.45 \mathrm{~d}$ \\
\hline
\end{tabular}

NOTE: S-W = Shapiro-Wilk Test, M = Mean, Med = Median, SD = Standard Deviation, IQR = Interquartile range. a-Median, b-Mean, c-Interquartile Range, d-Standard Deviation. Valuation of Mallery and George (2003): 1-Valuation "Good", 2-Valuation "Acceptable", 3-Valuation "Questionable"; $\alpha=0.05$ Risk. Source: Author's own compilation.

\subsection{Outliers}

Outliers are values which lie outside the normal range of data [43]; that is, beyond the interior limits. Interior limits are those obtained by adding and subtracting 1.5 times the Fspread to the percentile 75 or 25 . The Fspread is the distance between the quarters (percentiles 25 and 75). All outliers have been controlled. This procedure was repeated only once.

\subsection{Procedure}

The data were collected via a self-report questionnaire, with questions in two blocks:

- Personal aspects of the student and socio-demographic questions. Fundamentally, these will be independent variables.

- Data studied: knowledge, valuation and use of ICT in their present and past studies. Basically, these will be dependent variables.

Any omissions in the replies received two treatments:

- As for the items the socio-demographic and personal aspects: the interviewee was asked, and the questionnaire was completed subsequently.

- As for the items which are the object of the study: the omission was maintained. 


\section{Results}

\subsection{Relations Among the VOE-G, the Various Groups Overall}

The relations among the VOE-G capitalize on the initial interest. Taking into consideration these groups overall, we see these relations (Table 3):

Table 3. Relations among the VOE-G, without differentiating the groups.

\begin{tabular}{|c|c|c|c|c|}
\hline VOE-G & 2 & 3 & 4 & 5 \\
\hline \multirow{5}{*}{ Training in ICT-1 } & & & & $0.19(1)$ \\
\hline & $0.29(1)$ & $0.21(1)$ & $0.12(1)$ & $<0.001$ \\
\hline & $<0.001$ & $<0.001$ & 0.002 & $676(2)$ \\
\hline & $694(2)$ & $684(2)$ & $684(2)$ & \\
\hline & & $0.29(1)$ & $0.22(1)$ & \\
\hline \multirow{3}{*}{ Advantages offered by ICT- 2} & & $<0.001$ & $<0.001$ & \\
\hline & & $682(2)$ & $682(2)$ & \\
\hline & & & $0.54(1)$ & $0.90(1)$ \\
\hline \multirow{3}{*}{ General knowledge of ICT tools and resources- 3} & & & $<0.001$ & $<0.001$ \\
\hline & & & $683(2)$ & $682(2)$ \\
\hline & & & & $0.83(1)$ \\
\hline \multirow[t]{2}{*}{ General use of ICT tools and resources- 4} & & & & $<0.001$ \\
\hline & & & & $684(2)$ \\
\hline \multirow{3}{*}{ Knowledge and general use of ICT tools and resources-5 } & $0.30(1)$ & & & \\
\hline & $<0.001$ & & & \\
\hline & $675(2)$ & & & \\
\hline
\end{tabular}

(1)—Spearman's rho; (2)—n; $\alpha=0.05$ Risk; Source: Author's own compilation.

We can see that all the VOE-G are related in a significant and positive way.

\subsection{Relations Among the VOE-G Segmented by Sex}

When focusing attention on the relations between the global variables studied by means of gender (Table 4), significant and positive relationships can be seen to exist.

Table 4. Relations among the VOE-G, segmented by sex.

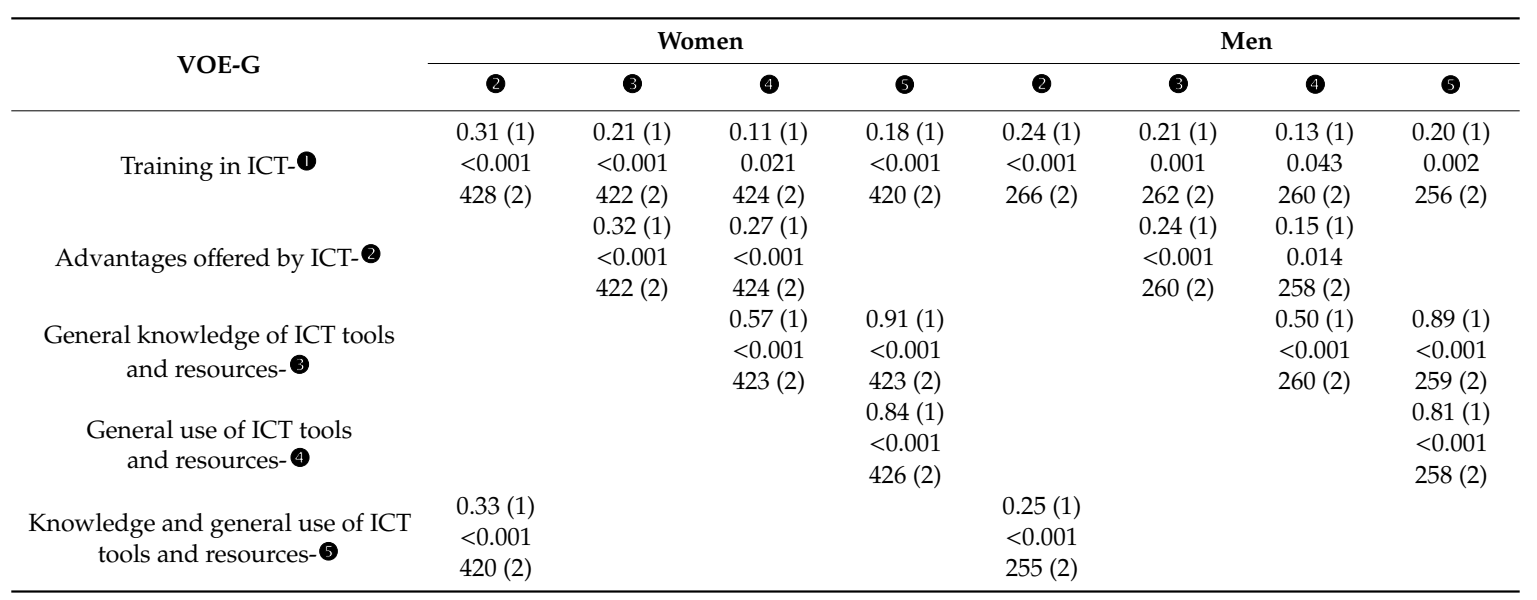

(1)—Spearman's rho; (2)—n; $\alpha=0.05$ Risk; Source: Author's own compilation.

\subsection{Relations Among the VOE-G; Segmented by Age}

Relations among the VOE-G were analysed in function of age (Table 5). To carry out this analysis, the variable Age (non-normal SW $=0.87, p<0.001$ ) was segmented in two levels: 1-up to 21 years and 2-21 years and above. 
Table 5. Relations between all VOE-G, segmented by age.

\begin{tabular}{|c|c|c|c|c|c|c|c|c|}
\hline \multirow{2}{*}{ VOE-G } & \multicolumn{4}{|c|}{ Up to 21 Years } & \multicolumn{4}{|c|}{21 Years and Above } \\
\hline & 2 & 3 & (4) & $\boldsymbol{\theta}$ & 2 & 8 & (4) & o \\
\hline \multirow{3}{*}{ Training in ICT-0 } & $0.38(2)$ & $0.21(2)$ & $0.11(2)$ & $0.18(2)$ & $0.22(2)$ & $0.21(2)$ & $0.12(2)$ & $0.20(2)$ \\
\hline & $<0.001$ & 0.001 & 0.097 & 0.005 & $<0.001$ & $<0.001$ & 0.012 & $<0.001$ \\
\hline & $242(3)$ & $243(3)$ & $244(3)$ & $242(3)$ & $452(3)$ & $441(3)$ & $440(3)$ & $434(3)$ \\
\hline \multirow{3}{*}{ Advantages offered by ICT- 2} & & $0.27(2)$ & $0.20(2)$ & & & $0.29(2)$ & 0.23 & \\
\hline & & $<0.001$ & 0.002 & & & $<0.001$ & $<0.001$ & \\
\hline & & $243(3)$ & $244(3)$ & & & $439(3)$ & $438(3)$ & \\
\hline \multirow{4}{*}{$\begin{array}{c}\text { General knowledge of ICT tools } \\
\text { and resources- } 3\end{array}$} & & & $0.51(1)$ & $0.89(1)$ & & & $0.56(2)$ & $0.90(2)$ \\
\hline & & & $<0.001$ & $<0.001$ & & & $<0.001$ & $<0.001$ \\
\hline & & & $247(3)$ & $246(3)$ & & & $436(3)$ & $436(3)$ \\
\hline & & & & $0.83(1)$ & & & & 0.84 \\
\hline General use of ICT tools & & & & $<0.001$ & & & & $<0.001$ \\
\hline and resources- $\boldsymbol{\theta}$ & & & & $247(3)$ & & & & $437(3)$ \\
\hline
\end{tabular}

(1)—Pearson's -r; (2)—Spearman's rho; (3)—n; $\alpha=.05$ Risk; Source: Author's own compilation.

The VOE-G variables, separated by age, are related in a significant and positive way with the exception of that of training in ICT as relates to general use of ICT tools and resources (in the group of up to 21 years), which shows a tendency towards significance.

\subsection{Relations Among the VOE-G Variables; Segmented by Means of University Access}

We analysed the relations among the VOE-G Variables, segmented in accordance with the means of university access (Table 6). Access for students older than 25 years of age was not considered. Accordingly, the grouping has two levels: by vocational training course and by the university access exam:

Table 6. Relations between all VOE-G Variables segmented by means of university access.

\begin{tabular}{|c|c|c|c|c|c|c|c|c|}
\hline \multirow{2}{*}{ VOE-G } & \multicolumn{4}{|c|}{ Vocational Training Course } & \multicolumn{4}{|c|}{ University Access Exam } \\
\hline & 2 & 3 & 4 & (5) & 2 & 3 & 4 & 5 \\
\hline \multirow{3}{*}{ Training in ICT-- } & $0.18(1)$ & $0.03(1)$ & $0.21(1)$ & $0.19(1)$ & $0.30(2)$ & $0.22(2)$ & $0.10(2)$ & $0.17(2)$ \\
\hline & $49(3)$ & $48(3)$ & $49(3)$ & $50(3)$ & $643(3)$ & $634(3)$ & $633(3)$ & $647(3)$ \\
\hline & & $0.44(1)$ & $0.24(1)$ & & & $0.28(2)$ & $0.22(2)$ & \\
\hline Advantages offered by ICT-2 & & 0.002 & 0.098 & & & $<0.001$ & $<0.001$ & \\
\hline \multirow{2}{*}{$\begin{array}{l}\text { General knowledge of ICT tools } \\
\text { and resources- } 3\end{array}$} & & & $<0.001$ & $<0.001$ & & & $<0.001$ & $<0.001$ \\
\hline & & & $49(3)$ & $49(3)$ & & & $632(3)$ & $642(3)$ \\
\hline \multirow{3}{*}{$\begin{array}{l}\text { General use of ICT tools } \\
\text { and resources- } \boldsymbol{\varphi}\end{array}$} & & & & $0.91(1)$ & & & & $0.83(2)$ \\
\hline & & & & $<0.001$ & & & & $<0.001$ \\
\hline & & & & $50(3)$ & & & & $641(3)$ \\
\hline $\begin{array}{l}\text { Knowledge and general use of ICT } \\
\text { tools and resources- } 5\end{array}$ & $0.35(1)$ & & & & $0.27(2)$ & & & \\
\hline
\end{tabular}

(1)—Pearson's-r; (2)—Spearman's rho; (3)—n; Risk $\alpha=0.05$; Source: Author's own compilation.

In the vocational training course path there is a significant and positive relation among the Advantages offered by ICT and the general knowledge of ICT tools and resources $(r=0.44, p=0.002)$, between the general knowledge of ICT tools and resources and the general use of ICT tools and resources $(r=0.65, p<0.001)$, and with the knowledge and general use of ICT tools and resources $(r=0.92, p<0.001)$, between the general use of ICT tools and resources and the knowledge and general use of ICT tools and resources $(\mathrm{r}=0.91, p<0.001)$ and between the Advantages offered by ICT and the Knowledge and general use of ICT tools and resources $(r=0.35, p=0.014)$. There also exists a tendency towards significance among the advantages offered by ICT and the General use of ICT tools and resources. There were no further relations of interest. In the university access exam path, all the relations are significant and positive. 


\subsection{Relations Among the VOE-G; Segmented by Holding Another University Degree}

The relations among VOE-G in function of holding another university degree were studied (Table 7):

Table 7. Relations between all VOE-G, segmented by holding of another university degree.

\begin{tabular}{|c|c|c|c|c|c|c|c|c|}
\hline \multirow{2}{*}{ VOE-G } & \multicolumn{4}{|c|}{ Not Holding Another University Degree } & \multicolumn{4}{|c|}{ Holding Another University Degree } \\
\hline & 2 & 3 & 4 & (5) & 2 & 3 & 4 & (5) \\
\hline \multirow{2}{*}{ Training in ICT-0 } & $0.29(2)$ & $0.22(2)$ & $0.12(2)$ & $0.20(2)$ & $0.28(1)$ & $-0.01(1)$ & $0.08(1)$ & $0.28(1)$ \\
\hline & $656(3)$ & $648(3)$ & $648(3)$ & $641(3)$ & $32(3)$ & $31(3)$ & $29(3)$ & $32(3)$ \\
\hline \multirow[b]{2}{*}{ Advantages offered by ICT-2 } & & $0.29(2)$ & $0.23(2)$ & & & $0.28(1)$ & $0.14(1)$ & \\
\hline & & $<0.001$ & $<0.001$ & & & 0.123 & 0.468 & \\
\hline \multirow{2}{*}{$\begin{array}{c}\text { General knowledge of ICT tools } \\
\text { and resources- } 3\end{array}$} & & & $<0.001$ & $<0.001$ & & & 0.045 & 0.000 \\
\hline & & & $649(3)$ & $648(3)$ & & & $29(3)$ & $29(3)$ \\
\hline \multirow{3}{*}{$\begin{array}{l}\text { General use of ICT tools } \\
\text { and resources- } \boldsymbol{4}\end{array}$} & & & & $0.83(2)$ & & & & $0.81(1)$ \\
\hline & & & & $<0.001$ & & & & 0.000 \\
\hline & & & & 649 (3) & & & & $29(3)$ \\
\hline $\begin{array}{l}\text { Knowledge and general use of ICT } \\
\text { tools and resource- } 5\end{array}$ & $0.30(2)$ & & & & $0.25(1)$ & & & \\
\hline
\end{tabular}

(1)—Pearson's-r; (2)—Spearman's rho; (3)—n; $\alpha=0.05$ Risk; Source: Author's own compilation.

Between those who do not hold another university degree all the relations analysed are significant and positive. Between those who do hold another university degree there are significant and direct relations between the general knowledge of ICT tools and resources and the general use of ICT tools and resources $(r=0.37, p=0.045)$, as well as in relation to the knowledge and general use of ICT tools and resources $(\mathrm{r}=0.84, p<0.001)$, and between the general use of ICT tools and resources and the knowledge and general use of ICT tools and resources $(r=0.81, p<0.001)$. There are no other significant relations.

3.6. Comparative Analysis, Comparisons of Medians. VOE-G in Function of Sex

We analysed whether differences exist in the VOE-G in function of sex (Table 8).

Table 8. VOE-G according to sex.

\begin{tabular}{|c|c|c|c|c|c|c|c|c|c|c|}
\hline \multirow{2}{*}{ VOE-G } & \multicolumn{4}{|c|}{ Women } & \multicolumn{4}{|c|}{ Men } & \multirow{2}{*}{$t, \mathrm{U}$} & \multirow{2}{*}{$p$} \\
\hline & S-W & $p$ & $\mathbf{M}$ & DT & S-W & $p$ & $\mathbf{M}$ & DT & & \\
\hline (1) Training in ICT & 0.99 & 0.002 & 20.56 & 4.03 & 0.99 & 0.020 & 20.88 & 3.96 & $55282(1)$ & 0.189 \\
\hline 2 Advantages offered by ICT & 0.99 & 0.032 & 44.16 & 6.23 & 0.99 & 0.026 & 45.24 & 6.78 & $52875.5(1)$ & 0.043 \\
\hline $\begin{array}{l}3 \text { General knowledge of ICT } \\
\text { resources and tools }\end{array}$ & 0.99 & 0.063 & 97.33 & 19.00 & 0.99 & 0.075 & 99.43 & 19.16 & $0.87(2)^{3}$ & 0.384 \\
\hline $\begin{array}{l}4 \text { General use of ICT } \\
\text { resources and tools }\end{array}$ & 0.99 & 0.010 & 92.73 & 16.34 & 0.98 & 0.001 & 92.64 & 16.00 & $56263.5(1)$ & 0.912 \\
\hline $\begin{array}{l}\text { (5 Knowledge and general use of } \\
\text { ICT resources and tools }\end{array}$ & 1.00 & 0.317 & 190.06 & 31.12 & 0.99 & 0.287 & 192.06 & 30.33 & $0.87(2)$ & 0.388 \\
\hline
\end{tabular}

NOTE: (- - Training in ICT, 2 -Advantages offered by ICT, $\mathbf{3}$-General knowledge of ICT tools and resources,

4-General use of ICT tools and resources, 5-Knowledge and general use of ICT tools and resources; $\mathrm{S}-\mathrm{W}=$ Shapiro-Wilk Test, $\mathrm{M}=$ Mean, SD: Standard Deviation, $p=p$-value; (1)—Mann-Whitney U Test, (2)— $t$-Student test; $\alpha=0.05$ Risk; Source: Author's own compilation.

There are significant differences $(U=52875.5, p=0.043)$ between men and women in the Advantages offered by ICT. Women perceive fewer advantages in the use of ICT than do men. There are no other differences of consideration.

\subsection{VOE-G in Function of Age}

We studied whether there are differences in the VOE-G in function of age (Table 9). 
Table 9. VOE-G according to age.

\begin{tabular}{|c|c|c|c|c|c|c|c|c|c|c|}
\hline \multirow{2}{*}{ VOE-G } & \multicolumn{4}{|c|}{ Up to 21 Years } & \multicolumn{4}{|c|}{21 Years and Above } & \multirow{2}{*}{$\mathbf{U}$} & \multirow{2}{*}{$p$} \\
\hline & S-W & $p$ & $\mathbf{M}$ & DT & S-W & $p$ & $\mathbf{M}$ & DT & & \\
\hline (1) Training in ICT & 0.99 & 0.034 & 21.35 & 3.81 & 0.99 & $<0.001$ & 20.31 & 4.06 & 48093 & 0.001 \\
\hline $\begin{array}{l}3 \text { General knowledge of ICT } \\
\text { resources and tools }\end{array}$ & 0.99 & 0.484 & 97.76 & 18.71 & 0.99 & 0.008 & 98.33 & 19.30 & 55007 & 0.945 \\
\hline $\begin{array}{l}(4 \text { General use of ICT } \\
\text { resources and tools }\end{array}$ & 0.99 & 0.217 & 93.63 & 14.93 & 0.99 & $<0.001$ & 92.17 & 16.85 & 53188 & 0.408 \\
\hline
\end{tabular}

NOTE: D_Training in ICT, 2_Advantages offered by ICT, 3 _ General knowledge of ICT tools and resources, 4-General use of ICT tools and resources, 5-Knowledge and general use of ICT tools and resources; $\mathrm{S}-\mathrm{W}=$ Shapiro-Wilk Test, $\mathrm{M}=$ Mean, SD: Standard Deviation, Mann-Whitney U Test, $p=p$-value; $\alpha=0.05$ Risk; Source: Author's own compilation.

There are significant differences in Training in ICT $(\mathrm{U}=48093, p=0.001)$, with the younger students being those who claim to have undergone a better training in ICT. There is a tendency towards significance in the advantages offered by ICT.

\subsection{VOE-G in Function of Means of University Access}

We analysed whether differences exist in the VOE-G according to the means of university access (Table 10).

Table 10. VOE-G according to means of university access.

\begin{tabular}{|c|c|c|c|c|c|c|c|c|c|c|}
\hline \multirow{2}{*}{ VOE-G } & \multicolumn{4}{|c|}{ Vocational Training Course } & \multicolumn{4}{|c|}{ University Access Exam } & \multirow{2}{*}{ U } & \multirow{2}{*}{$p$} \\
\hline & S-W & $p$ & $\mathbf{M}$ & DT & S-W & $p$ & $\mathbf{M}$ & DT & & \\
\hline (- Training in ICT & 0.97 & 0.223 & 19.78 & 4.15 & 0.99 & $<0.001$ & 20.68 & 4.04 & 13972.5 & 0.088 \\
\hline (2) Advantages offered by ICT & 0.98 & 0.497 & 45.36 & 7.67 & 0.99 & 0.001 & 44.62 & 6.47 & 15147 & 0.423 \\
\hline $\begin{array}{l}\text { (3) General knowledge of ICT } \\
\text { resources and tools }\end{array}$ & 0.95 & 0.055 & 95.33 & 19.49 & 0.99 & 0.003 & 97.61 & 19.88 & 13909.5 & 0.177 \\
\hline $\begin{array}{l}\text { ( General use of ICT } \\
\text { resources and tools }\end{array}$ & 0.98 & 0.556 & 90.68 & 17.87 & 0.99 & $<0.001$ & 92.11 & 16.72 & 15204 & 0.546 \\
\hline $\begin{array}{l}\text { 6 Knowledge and general use of } \\
\text { ICT resources and tools }\end{array}$ & 0.92 & 0.002 & 181.47 & 42.56 & 0.97 & $<0.001$ & 187.10 & 36.37 & 15214.5 & 0.289 \\
\hline
\end{tabular}

The only noticeable issue according to the means of university access is the tendency towards significance in training in ICT.

\subsection{VOE-G in Function of Holding Another University Degree}

We analysed whether there are differences in the VOE-G in function of holding another university degree (Table 11).

There are significant differences $(U=6871.5, p<0.001)$ in perceptions on training in ICT according to the holding or not of another university degree: those who do not hold another university degree claim to have undergone a better training in ICT than those who do have another degree. 
Table 11. VOE-G in function of holding another university degree.

\begin{tabular}{|c|c|c|c|c|c|c|c|c|c|c|}
\hline \multirow{2}{*}{ VOE-G } & \multicolumn{4}{|c|}{ No } & \multicolumn{4}{|c|}{ Yes } & \multirow{2}{*}{$t, U$} & \multirow{2}{*}{$p$} \\
\hline & S-W & $p$ & $\mathbf{M}$ & DT & S-W & $p$ & $\mathbf{M}$ & DT & & \\
\hline (1) Training in ICT & 0.99 & $<0.001$ & 20.80 & 3.94 & 0.95 & 0.115 & 17.97 & 4.20 & $6871.5(1)$ & $<0.001$ \\
\hline $\begin{array}{l}3 \text { General knowledge of ICT } \\
\text { resources and tools }\end{array}$ & 0.99 & 0.008 & 98.38 & 19.05 & 0.98 & 0.751 & 97.45 & 17.42 & $9440(1)$ & 0.492 \\
\hline $\begin{array}{l}4 \text { General use of ICT } \\
\text { resources and tools }\end{array}$ & 0.99 & $<0.001$ & 92.80 & 16.11 & 0.98 & 0.772 & 91.41 & 16.10 & $9181.5(1)$ & 0.526 \\
\hline
\end{tabular}

NOTE: D_Training in ICT, 2_Advantages offered by ICT, 3 _ General knowledge of ICT tools and resources, 4-General use of ICT tools and resources, 5-Knowledge and general use of ICT tools and resources; $\mathrm{S}-\mathrm{W}=$ Shapiro-Wilk Test, $\mathrm{M}=$ Mean, SD:Standard Deviation, Mann-Whitney U Test, $p=p$-value; (1)—Mann-Whitney U Test, (2)— $t$-Student test; $\alpha=0.05$ Risk; Source: Author's own compilation.

\subsection{VOE-G in the Levels of Training in ICT and the Advantages of ICT}

Training in ICT ("training") and advantages offered by ICT ("Advantages") have been segmented into two levels (non-normal), taking as the fulcrum their medians (MedTraining $=21$, MedAdvantages $=44$ ): Training having two levels (1-little training, up to 21 points, 2 -considerable training, 21 points and above), and advantages having two levels (1-Few advantages, up to 44 points, 2-Many advantages, 44 points and above). We analysed the differences in the VOE-G according to the levels of training in ICT and advantages offered by ICT (Table 12).

Table 12. VOE-G in the levels of Training received and Advantages perceived.

\begin{tabular}{|c|c|c|c|c|c|c|c|c|c|c|}
\hline VOE-G & S-W & $p$ & $\mathbf{M}$ & DT & S-W & $p$ & $\mathbf{M}$ & DT & \multirow{2}{*}{$\mathbf{U}$} & \multirow{2}{*}{$p$} \\
\hline Training & \multicolumn{4}{|c|}{ Little Training in ICT } & \multicolumn{4}{|c|}{ Considerable Training in ICT } & & \\
\hline $\begin{array}{l}\text { (1) General knowledge of ICT } \\
\text { tools and resources }\end{array}$ & 0.99 & 0.022 & 94.59 & 17.13 & 0.99 & 0.006 & 100.94 & 20.52 & 47184 & $<0.001$ \\
\hline $\begin{array}{l}2 \text { General use of ICT tools } \\
\text { and resources }\end{array}$ & 0.99 & 0.003 & 90.67 & 15.08 & 0.98 & 0.001 & 94.04 & 17.33 & 51700.5 & 0.009 \\
\hline $\begin{array}{l}3 \text { Knowledge and general use } \\
\text { of ICT tools and resources }\end{array}$ & 1.00 & 0.323 & 185.26 & 28.62 & 0.99 & 0.016 & 194.98 & 32.71 & 46879.5 & $<0.001$ \\
\hline Advantages & \multicolumn{4}{|c|}{ Few advantages in ICT } & \multicolumn{4}{|c|}{ Many advantages in ICT } & & \\
\hline $\begin{array}{l}\text { (1) General knowledge of ICT } \\
\text { tools and resources }\end{array}$ & 0.99 & 0.265 & 93.15 & 17.22 & 0.98 & $<0.001$ & 102.53 & 19.75 & 40756 & $<0.001$ \\
\hline $\begin{array}{l}2 \text { General use of ICT tools } \\
\text { and resources }\end{array}$ & 0.99 & 0.042 & 89.75 & 15.88 & 0.98 & $<0.001$ & 95.15 & 16.18 & 45480.5 & $<0.001$ \\
\hline $\begin{array}{l}3 \text { Knowledge and general use } \\
\text { of ICT tools and resources. }\end{array}$ & 1.00 & 0.464 & 182.90 & 29.50 & 0.98 & $<0.001$ & 197.68 & 30.71 & 39474 & $<0.001$ \\
\hline
\end{tabular}

There are significant differences in the levels of general knowledge of ICT tools and resources $(\mathrm{U}=47,184, p<0.001)$, in general use of ICT tools and resources $(\mathrm{U}=51,700.5, p=0.009)$, and in knowledge and general use of ICT tools and resources $(\mathrm{U}=46,879.5, p<0.001)$ in function of the training in ICT to which they report. A result of this is that those claiming to have the most Training show higher levels in the use and knowledge of information technology. Significant differences can be seen in the levels of general knowledge of ICT tools and resources $(U=40,756, p<0.001)$, in general use of ICT tools and resources $(\mathrm{U}=45,480.5, p<0.001)$, and in those of knowledge and general use of ICT tools and resources $(\mathrm{U}=39,474, p<0.001)$ in function of the advantages that they claim to perceive in ICT. In other words, those who claim to see more advantages show higher levels than those who perceive fewer advantages.

All the above analyses result in our acceptance of the stated hypotheses of the study, identifying that the students who used ICT tools and digital learning materials in their secondary education show 
a greater knowledge of the advantages in using ICT in their learning process than those students who did not use this type of material. On the other hand, those students who entered university via a Vocational training course show a greater knowledge of ICT than those students who entered via the university access exam or through an access scheme for students above 25 years of age.

\section{Discussion}

This study explored the relationship between the knowledge and use of digital technologies prior to university and then during higher education studies, expanding on the vision of previous studies [42].

As noted by the European Commission [22], the social digitalization found in member states produces a series of demands to which the education system needs to adequately train students to give answers; therefore, throughout the various stages of education students should receive an appropriate digital training in order to prepare them for professional training. Students and teachers nowadays make continuous use of technology in the teaching-learning process at all educational levels $[27,28]$. Nevertheless, as is shown in the present study, important shortcomings are still found among students in making an adequate use of the same in their learning processes. That said, it is necessary to take account of certain factors such as age, gender, means of entrance/access to university and qualifications, as these present considerable differences, as demonstrated by the results herein presented.

These technologies seek to achieve new objectives, constantly linking them with new, emergent technologies which increase the students' motivation both before and after their time at university and which assist them in the creation and assimilation of knowledge [48]. Nevertheless, the current study shows that, when it comes to making an appropriate use of these new technologies in learning processes, there are still important shortcomings in the students. Studies such as that of [49] stress the importance in making use of these tools, as well as creativity and critical thinking, in a combination of methods and activities. It is necessary, though, to consider certain factors such as age, gender, means of access to university and other university degrees held by a student, as in these variables significant differences are to be found, as demonstrated by the results in this paper.

Clearly, in line with certain authors $[32,33,48]$, the use of technology has not resulted in an improvement in quality, rather it is a competence that needs to be improved in training, with continuous work being required to improve the quality of teaching. So, recognizing that technology is a tool or a medium in which the student must be trained, in order to become a link in the chain of improved quality, it has to be stated that this aim has not so far been achieved, although the educational community is continuing to work towards it.

According to authors such as Area [32], Law et al. [33], and Lugo \& Kelly [50], technology has not brought about an improvement in quality, but is rather a competence which needs to be progressively improved in education so as to raise the level of teaching. As a consequence, one can say that technology is a tool or a medium in which the student needs to be trained, in order to be a link in the improvement of standards, but which aim has up till now not been fulfilled, and that the educational community needs to continue working along these lines. These digital educational tools allow for an interaction between students, teachers, and teaching resources and, in a continuous and significant volume, create data which can be analysed by applying a variety of methodologies [51].

Education, at whatever stage, offers the necessary conditions in its relation with technology in the classroom to optimize the learning-teaching process and promote the transferal of knowledge and skills. The fundamental basis for this process is the student's attitude [52], an important question which needs to be addressed in the design and development of learning materials [53]. Learning environments, both before and after university, should reflect the possible uses for the knowledge which is expected of students [54], so as to avoid the loss of skills once they have been gained $[55,56]$. Finally, given that one finds different abilities and perceptions in the classroom, in so far as the use of ICT is concerned, these differences should be regarded as one of the key criteria for the practice of an efficient teaching-learning process in the classroom [57-59]. 
Furthermore, current studies [60] demonstrate other factors that could influence this perception: the socio-economic origin of the students, the access to technology of their fellow students and teachers, and the resources which they have available outside the educational centre can all impact upon the ability with which they use technology. Although the technological infrastructure of the centres is not of itself a significant element in determining a student's digital competence, the general availability of technological equipment in an educational institution could well be a requisite for the student to obtain this support from fellow students and teachers. As a result, it is of fundamental importance to examine the use which each and every teacher in secondary and higher education makes of these ICT, and how their identities are thus reflected, while simultaneously contributing to knowledge creation and academic performance [61]. In the research conducted by Zhong [62], the availability of ICT facilities in educational centres is linked to the students' self-perception of their digital skills, but the type of school was not found to have a significant influence. Also, in general, adolescents' access to ICT in the home, their socio-economic situation, and their history of use of ICT are positively associated with the self-perception of their digital skills. In this regard, the authorities responsible should adapt the educational environment to suit the needs and abilities of the students, in a wholescale way, from pre-university levels, and should encourage high levels of digital competence in teaching staff.

\section{Conclusions}

The results show that the students who used ICT in their secondary schooling, irrespective of age and gender, have a higher knowledge and make a better use of them in their learning process at university, since they are already aware of the advantages offered by ICT.

It has been shown that there are significant relations between the Variables Studied, when analysing the sample. When the data were segmented by sex, the relations between variables continue to be significant and positive. When segmenting by age, the significance is maintained, with some exceptions in the age group of up to 21 years. As for the students who enter university by means of a vocational training course there is a significant and positive relation between the variables of advantages offered by ICT and general knowledge of ICT tools and resources as well as between general knowledge of ICT tools and resources and general use of ICT tools and resources and advantages offered by ICT. As for the students who enter university by means of the university access exam all relations are significant and positive. As for the students who do not have another university degree the relations between variables are significant and positive and for those students who do have another university degree the relations are significant between general knowledge of ICT tools and resources and general use of ICT tools and resources, also with the knowledge and general use of ICT tools and resources. There are also significant relations between general use of ICT tools and resources and knowledge and general use of ICT tools and resources. As regards the comparison of medians, in terms of sex, it is women who score lower in the perception of Advantages offered by ICT. In function of age, there are significant differences in training in ICT, where younger students obtain better valuations. In function of whether the student holds another university degree, those who do hold another degree respond that they have received a better training.

Lastly, there are significant differences in the levels of general knowledge of ICT tools and resources, in general use of ICT tools and resources, and in knowledge and general use of ICT tools and resources: the greater the training a student has, the higher their levels in all of these. Significant differences are shown in general knowledge of ICT tools and resources, in general use of ICT tools and resources, and in knowledge and general use of ICT tools and resources: the greater the perception by a student of the advantages offered by ICT, the higher their levels in all of these.

All these data illustrate a need for training students in digital technology prior to their university studies, since this will equip them with a higher level of digital competence which can benefit their academic achievement. 
Limitations in the study were also noted. We have analysed a specific context, in which the results can be proven by the characteristics of the students in the particular university where we carried out the study. The study was conducted under controlled conditions, which fact could have influenced the attitudes of the students. Despite these limitations, it should be noted that this investigation widens the field of study which relates university students' perception of their knowledge and use of digital technology to their prior academic experience. However, it would be interesting to further examine these results by means of tools which yield a precise measurement, by placing students in a situation where they must decide what use to make of digital technology in a more specific context. Various studies have already identified important differences in the levels of self-perception and performance tests in certain aspects of digital competence [63].

Author Contributions: Conceptualization, F.A.M.G., M.R.F.-S., and F.L.-S; methodology, F.A.M.G. and. J.L.C.d.C.; software, F.A.M.G. and J.L.C.d.C.; validation, F.A.M.G. and J.L.C.d.C.; formal analysis, F.A.M.G., F.L.-S., and M.R.F.-S.; investigation, F.A.M.G.; resources, F.A.M.G., F.L.-S., and M.R.F.-S.; data curation, F.A.M.G. and J.L.C.d.C.; writing — original draft preparation, F.A.M.G., F.L.-S., and M.R.F.-S.; writing—review and editing, F.A.M.G., F.L.-S., and M.R.F.-S.; visualization, F.A.M.G., F.L.-S., and M.R.F.-S.; supervision, F.A.M.G., F.L.-S., M.R.F.-S., and J.L.C.d.C. All authors have read and agreed to the published version of the manuscript.

Funding: This research received no external funding.

Conflicts of Interest: The authors declare no conflict of interest.

\section{References}

1. Reig, D. Un mundo de medios sin fin. Cambios en aprendizaje, Facebook y la apoteosis de las aplicaciones expresivas. In El Proyecto Facebook Y la Posuniversidad. Sistemas Operativos Sociales Y Entornos Abiertos de Aprendizaje; Ariel: Madrid, Spain, 2010; pp. 183-202.

2. Nowak, M.; Highfield, R. SuperCooperators: Altruism, Evolution, and Why We Need Each Other to Succeed; Simon and Schuster: New York, NY, USA, 2011; ISBN 978-1-4391-1017-1.

3. Ferrés, J. Las Pantallas y el Cerebro Emocional; Gedisa: Barcelona, Spain, 2014.

4. Jenkins, H. Convergence Culture: La Cultura de la Convergencia de los Medios de Comunicación; Ediciones Paidós: Barcelona, Spain, 2008; ISBN 978-84-493-2153-5.

5. Piscitelli, A. Nativos Digitales: Dieta Cognitiva, Inteligencia Colectiva y Arquitecturas; Santillana: Buenos Aires, Argentina, 2009.

6. Zickurh, K.; Madden, M. Older Adults and Internet Use; Pew Research Center's Internet \& American Life Project: Washington, DC, USA, 2012.

7. García, N.; Cruces, F.; Urteaga, M. Jóvenes, Culturas Urbanas y Redes Digitales; Ariel: Madrid, Spain, 2012.

8. Dede, C. Comparing frameworks for 21st century skills. In 21st Century Skills: Rethinking How Students Learn; Solution Tree Press: Bloomington, IN, USA, 2010; pp. 51-76.

9. Davies, A.; Fidler, D.; Gorbis, D. Future Work Skills 2020; Institute for the Future for University of Phoenix Research Institute: Palo Alto, CA, USA, 2011.

10. Downes, S. Connectivism and Connective Knowledge: Essays on Meaning and Learning Networks; National Research Council Canada: Corner Brook, NL, Canada, 2012.

11. Sharples, M.; Spikol, D. Mobile learning. In Technology Enhanced Learning: Research Themes; Springer: Berlin, Germany, 2017; pp. 89-96.

12. Cobo Romaní, J.C.; Moravec, J.W. Aprendizaje Invisible: Hacia una Nueva Ecología de la Educación; Publicacions i Edicions de la Universitat de Barcelona: Barcelona, Spain, 2011; ISBN 978-84-475-3517-0.

13. Ferrari, A. Digital Competence in Practice: An Analysis of Frameworks; Publications Office of the European Union: Luxembourg, 2012.

14. Bawden, D. Origins and concepts of digital literacy. In Digital Literacies-Concepts, Policies and Practices; Peter Lang Publishing: New York, NY, USA, 2008; pp. 17-32.

15. Krumsvik, R.J. Situated learning and teachers' digital competence. Educ. Inf. Technol. 2008, 13, $279-290$. [CrossRef] 
16. Van Deursen, A.J.A.M.; van Dijk, J.A.G.M. Using the Internet: Skill related problems in users' online behavior. Interact. Comput. 2009, 21, 393-402. [CrossRef]

17. Ferrés, J.; Piscitelli, A. La competencia mediática: Propuesta articulada de dimensiones e indicadores. Comun. Rev. Científica Comun. Educ. 2012, 19, 75-82. [CrossRef]

18. Gutiérrez-Martín, A.; Tyner, K. Educación para los medios, alfabetización mediática y competencia digital. Comun. Rev. Científica Comun. Educ. 2012, 19, 31-39. [CrossRef]

19. De Pablos Pons, J.; Bravo, P.C.; Jiménez, J.C.; de Cózar, S.R. La competencia digital de los estudiantes de educación no universitaria: Variables predictivas. Bordón Rev. Pedagog. 2017, 69, 169-185. [CrossRef]

20. From, J. Pedagogical digital competence-Between values, knowledge and skills. High. Educ. Stud. 2017, 7, 43. [CrossRef]

21. Rodríguez-García, A.-M.; Sánchez, F.R.; Ruiz-Palmero, J. Competencia digital, educación superior y formación del profesorado: Un estudio de meta-análisis en la web of science. Píxel-Bit Rev. Medios Educ. 2019, 65-82. [CrossRef]

22. European Commission. Digital Education at School in Europe. Eurydice Report; Publications Office of the European Union: Luxembourg, 2019.

23. Ito, M.; Gutiérrez, C.M.; Livingstone, S.; Penuel, B.; Rhodes, J.; Salen, K.; Schor, J.; Sefton-Green, J.; Watkins, C. Connected Learning: An Agenda for Research and Design; Digital Media and Learning Research Hub: Irvine, CA, USA, 2013.

24. Jenkins, H.; Clinton, K.; Robison, R.; Weigel, M. Confronting the Challenges of Participatory Culture: Media Education for the 21st Century; The MacArthur Foundation: Chicago, IL, USA, 2009.

25. Lankshear, C.; Knobel, M. New Literacies; McGraw-Hill Education: London, UK, 2011.

26. Lieberman, H. User interface goals, AI opportunities. AI Mag. 2009, 30, 16. [CrossRef]

27. Gisbert, M.; Esteve, F. Digital Leaners: La competencia digital de los estudiantes universitarios. Cuestión Univ. 2016, 7, 48-59.

28. Gudmundsdottir, G.B.; Hatlevik, O.E. Newly qualified teachers' professional digital competence: Implications for teacher education. Eur. J. Teach. Educ. 2018, 41, 214-231. [CrossRef]

29. Cuban, L.; Kirkpatrick, H.; Peck, C. High access and low use of technologies in high school classrooms: Explaining an apparent paradox. Am. Educ. Res. J. 2001, 38, 813-834. [CrossRef]

30. Zhao, Y.; Pugh, K.; Sheldon, S.G.; Byers, J.L. Conditions for classroom technology innovations. Teach. Coll. Rec. 2002, 104, 482-515. [CrossRef]

31. Kozma, R.B. Technology, Innovation, and Educational Change: A Global Perspective: A Report of the Second Information Technology in Education Study, Module 2; ISTE International Society for Technology in Education: Washington, DC, USA, 2003; ISBN 978-1-56484-230-5.

32. Area, M. Veinte anos de politicas institucionales para incorporar las tecnologias de la informacion y comunicacion al sistema escolar. In Tecnologías Para Transformar la Educación; AKAL: Madrid, Spain, 2006; pp. 199-232.

33. Law, N.; Pelgrum, W.J.; Plomp, T. Pedagogy and ICT Use; Springer: Dordrecht, The Netherlands, 2008.

34. Ghavifekr, S.; Rosdy, W.A.W. Teaching and learning with technology: Effectiveness of ICT integration in schools. Int. J. Res. Educ. Sci. 2015, 1, 175-191. [CrossRef]

35. Colás Bravo, P.; Reyes de Cózar, S.; Conde Jiménez, J. El uso de las TIC en las aulas como factor predictivo del estado emocional de los estudiantes. Rev. Qurriculum 2018, 31, 9-30. [CrossRef]

36. Pérez-Escoda, A.; Castro-Zubizarreta, A.; Fandos-Igado, M. La competencia digital de la Generación Z: Claves para su introducción curricular en la Educación Primaria. Comun. Rev. Científica Comun. Educ. 2016, 24, 71-79. [CrossRef]

37. Kennedy, G.E.; Judd, T.S.; Churchward, A.; Gray, K.; Krause, K.-L. First year students' experiences with technology: Are they really digital natives? Australas. J. Educ. Technol. 2008, 24, 24. [CrossRef]

38. Gros, B.; Garcia, I.; Escofet, A. Beyond the net generation debate: A comparison between digital learners in face-to-face and virtual universities. Int. Rev. Res. Open Distrib. Learn. 2012, 13, 190-210. [CrossRef]

39. López-Meneses, E.; Sirignano, F.M.; Vázquez-Cano, E.; Ramírez-Hurtado, J.M. University students' digital competence in three areas of the DigCom 2.1 model: A comparative study at three European universities. Australas. J. Educ. Technol. 2020, 36, 69-88. [CrossRef] 
40. Gisbert, M.; Espuny, C.; González, J. INCOTIC. A diagnostic self-assessment tool for digital competences in university studies. Profr. Rev. Curric. Form. Profr. 2011, 15, 75-90.

41. Aesaert, K.; Voogt, J.; Kuiper, E.; van Braak, J. Accuracy and bias of ICT self-efficacy: An empirical study into students' over-and underestimation of their ICT competences. Comput. Hum. Behav. 2017, 75, 92-102. [CrossRef]

42. Martínez-Lopez, R.; Yot Domínguez, C.; Trigo, M.E. Analysis of the internet use and students' Web 2.0 digital competence in a Russian university. Int. J. Technol. Enhanc. Learn. 2020, 12, 316. [CrossRef]

43. García-Valcárcel Muñoz-Repiso, A.; TejedorTejedor, F.J. Percepción de los estudiantes sobre el valor de las TIC en sus estrategias de aprendizaje y su relación con el rendimiento. Educación XX1 2017, 20. [CrossRef]

44. Verhoeven, J.C.; Heerwegh, D.; De Wit, K. First year university students' self-perception of ICT skills: Do learning styles matter? Educ. Inf. Technol. 2012, 17, 109-133. [CrossRef]

45. Almerich Cerveró, G.; Suárez Rodríguez, J.M.; Jornet Meliá, J.M.; Orellana Alonso, M.N. Las competencias y el uso de las Tecnologías de Información y Comunicación (TIC) por el profesorado: Estructura dimensional. Rev. Electrónica Investig. Educ. 2011, 13, 28-42.

46. Tondeur, J.; Braak, J.V.; Valcke, M. Curricula and the use of ICT in education: Two worlds apart? Br. J. Educ. Technol. 2007, 38, 962-976. [CrossRef]

47. Van Braak, J.; Tondeur, J.; Valcke, M. Explaining different types of computer use among primary school teachers. Eur. J. Psychol. Educ. 2004, 19, 407. [CrossRef]

48. Parra, M.E.; Segura, A.; Romero-García, C. Análisis del pensamiento creativo y niveles de activación del alumno tras una experiencia de gamificación. Educar 2020, 56, 475-489.

49. Cuetos Revuelta, M.J.; Grijalbo Fernández, L.; Argüeso Vaca, E.; Escamilla Gómez, V.; Ballesteros Gómez, R. Potencialidades de las TIC y su papel fomentando la creatividad: Percepciones del profesorado. RIED Rev. Iberoam. Educ. Distancia 2020, 23, 287-306. [CrossRef]

50. Lugo, M.T.; Kelly, V. La Matriz Tic. Una Herramienta Para Planificar Las Tecnologías de la Información Y Comunicación en Las Instituciones Educativas; IIPE-UNESCO Sede Regional Buenos Aires: Buenos Aires, Argentina, 2011.

51. Tapia Silva, H.G. Actitud hacia las TIC y hacia su integración didáctica en la formación inicial docente. Actual. Investig. En Educ. 2018, 18. [CrossRef]

52. Collins, A. Design issues for learning environments. In International Perspectives on the Design of Technology-Supported Learning Environments; Lawrence Erlbaum: Mahwah, NJ, USA, 1996; pp. 813-834.

53. Abarca Amador, Y. El uso de las TIC en la educación universitaria: Motivación que incide en su uso y frecuencia. Rev. Leng. Mod. 2015. [CrossRef]

54. Bransford, J.D.; Sherwood, R.D.; Hassenbring, T.S.; Kinzer, C.K.; Williams, S.M. Anchored instruction: Why we need it and how technology can help. In Cognition, Education, and Multimedia: Exploring Ideas in High Technology; Lawrence Erlbaum Associates, Inc.: Mahwah, NJ, USA, 1990; pp. 115-141.

55. Knuth, R.A.; Cunningham, D.J. Tools for constructivism. In Designing Environments for Constructive Learning; Duffy, T.M., Lowyck, J., Jonassen, D.H., Welsh, T.M., Eds.; NATO ASI Series F; Springer: Berlin/Heidelberg, Germany, 1993; pp. 163-188. ISBN 978-3-642-78069-1.

56. Lanuza Gámez, F.I.; Rizo Rodríguez, M.; Saavedra Torres, L.E. Uso y aplicación de las TIC en el proceso de enseñanza-aprendizaje. Rev. Científica FAREM Esteli 2018, 16-30. [CrossRef]

57. Bearne, E. Differentiation and Diversity in the Primary School; Routledge: London, UK, 1996.

58. Kerry, T.; Kerry, C.A. Differentiation: Teachers' views of the usefulness of recommended strategies in helping the more able pupils in primary and secondary classrooms. Educ. Stud. 1997, 23, 439-457. [CrossRef]

59. Wang, M.C. Learning characteristics of pupils with special needs and the provision of effective schooling. In Special Education: Research E Practice: Synthesis of Findings; Pergamon Press: New York, NY, USA, 1990; pp. 1-34.

60. Manzano, D.; Fernández-Mellizo, M. Origen familiar, uso del tiempo y de las tecnologías de la información. Rev. Int. Sociol. 2019, 77, 136. [CrossRef]

61. Aróstegui, J.L.; Guerrero, J.L. The role of ITs in improving teaching quality in schools: A multicase study. Multidiscip. J. Educ. Res. 2014, 4, 101-124. [CrossRef] 
62. Zhong, Z.-J. From access to usage: The divide of self-reported digital skills among adolescents. Comput. Educ. 2011, 56, 736-746. [CrossRef]

63. Rohatgi, A.; Scherer, R.; Hatlevik, O.E. The role of ICT self-efficacy for students' ICT use and their achievement in a computer and information literacy test. Comput. Educ. 2016, 102, 103-116. [CrossRef]

Publisher's Note: MDPI stays neutral with regard to jurisdictional claims in published maps and institutional affiliations.

(C) 2020 by the authors. Licensee MDPI, Basel, Switzerland. This article is an open access article distributed under the terms and conditions of the Creative Commons Attribution (CC BY) license (http://creativecommons.org/licenses/by/4.0/). 